\title{
FRIEDRICH-ALEXANDER-UNIVERSITÄT
}

ERLANGEN-NÜRNBERG

Lehrstuhl für VWL, insbes. Arbeitsmarkt- und Regionalpolitik

Professor Dr. Claus Schnabel

Diskussionspapiere

Discussion Papers

No. 10

German Works Councils Old and New:

Incidence, Coverage and Determinants

John T. Addison, Lutz Bellmann, Claus Schnabel and JOACHIM WAGNER

MAY 2002

Editor: Prof. Dr. Claus Schnabel, Friedrich-Alexander-Universität Erlangen-Nürnberg ( ) John T. Addison, Lutz Bellmann, Claus Schnabel and Joachim Wagner 


\section{German Works Councils Old and New: Incidence, Coverage and Determinants *}

John T. Addison ${ }^{\mathrm{a}}$, Lutz Bellmann ${ }^{\mathrm{b}}$, Claus Schnabel ${ }^{\mathrm{c}}$, and Joachim Wagner ${ }^{\mathrm{d}}$

ABSTRACT: Although works councils are a core element of the German system of industrial relations, there is little reliable information on their incidence and coverage. This paper uses data from the nationally representative IAB establishment panel to fill this gap. We examine the frequency of works councils by establishment size and broad sector for eastern and western Germany, while at the same time charting the determinants of their presence. Furthermore, we identify newly established works councils and provide the first econometric analysis of the circumstances of their formation. Finally, we discuss the consequences of our findings for economic analysis of the institution and for public policy.

ZUSAMMENFASSUNG: Trotz ihrer großen Bedeutung im deutschen System der Arbeitsbeziehungen gibt es kaum gesicherte Erkenntnisse über den Verbreitungsund Deckungsgrad von Betriebsräten. Diese Forschungslücke soll in der vorliegenden Arbeit durch Verwendung von repräsentativen Daten des IABBetriebspanels geschlossen werden. Dabei wird die Verbreitung von Betriebsräten nach Firmengröße und Sektoren sowie für West- und Ostdeutschland ebenso analysiert wie deren Bestimmungsgründe. Zudem wird erstmals die Einrichtung neuer Betriebsräte ökonometrisch untersucht. Abschließend erörtern wir die ökonomischen und wirtschaftspolitischen Implikationen unserer Ergebnisse.

KEYWORDS: Works Councils, Works Constitution Act, Germany

JEL-CLASSIFICATION: J50, J53

* This study uses data from the IAB establishment panel, which is financially supported by the European Social Fund. We are indebted to Holger Alda of the IAB for his help with the data. An earlier version of this paper was presented in February 2002 at a workshop of the University of Witten/Herdecke; we thank the participants for helpful comments.

a Prof. Dr. John T. Addison, Department of Economics, Moore School of Business, University of South Carolina (U.S.A.), Columbia SC 29208, USA and IZA (Germany), ecceaddi@moore.sc.edu.

${ }^{b}$ Dr. Lutz Bellmann, Institut für Arbeitsmarkt- und Berufsforschung der Bundesanstalt für Arbeit and IZA (Germany), Regensburger Straße 104, D-90478 Nürnberg, lutz.bellmann@iab.de.

c Prof. Dr. Claus Schnabel, Friedrich-Alexander-Universität Erlangen-Nürnberg, Lehrstuhl für Arbeitsmarkt-

und Regionalpoltik, Lange Gasse 20, D-90403 Nürnberg, claus.schnabel@wiso.uni-erlangen.de.

d Prof. Dr. Joachim Wagner, Universität Lüneburg, Institut für Volkswirtschaftslehre, D-21332 Lüneburg, HWWA and IZA (Germany), wagner@uni-lueneburg.de 


\section{MOtIVATION}

After protracted and highly controversial debate, the German Bundestag passed the law reforming the pre-existing Works Constitution Act (Betriebsverfassungsgesetz) on June 22, 2001. The new Works Constitution Reform Act (BetrVerfReformgesetz) was approved by the Bundesrat on July 13, 2001, and became effective on July 28,2001 , the day after its announcement in the Federal Law Bulletin (Bundesgesetzblatt). ${ }^{1}$

Section 1 of both the old and the new law provide for the election of works councils in all establishments that normally have five or more employees with voting rights, including three who are eligible to be works councilors. (Voting rights accrue to all workers aged 18 years and above, and eligible employees are all workers who have been employed by the firm for at least six months.) Although leaving this particular size threshold unchanged, the new legislation seeks to facilitate works council formation through simplified election procedures, inter al. This goal reflects the limited penetration of works councils: in the majority of small establishments, works council plants are a distinct minority, despite the low employment size criterion and strict sanctions against employers who attempt to interfere with the process of works council formation. Note also that the new legislation does make a large number of formal changes that have the effect of increasing the power and authority of works councils, with the stated aim of improving the economic performance of the institution.

In short, the central aim of the German government in framing the legislation was to increase the number (and reach) of works councils and thereby shrink the size of what was termed a 'codetermination-free zone' by the Kommission Mitbestimmung (Codetermination Commission), a high-level group of experts set up to evaluate, among other things, the experience with the workings of the old Works Constitution Act of $1972 .^{2}$ According to the Commission's final report, issued in

\footnotetext{
${ }^{1}$ There is as yet no official English-language version of the law. The Works Constitution Reform Act, documenting changes between the old and the new law, is published in Deutscher Bundestag, 14. Wahlperiode, Drucksache 14/5741 vom 2. April 2001, and is available on the web at: www.bundestag.de. The new Act is published in stand-alone form in the Bundesgesetzblatt BGBI.I S. 1852, and is available on the web at: www.bma.bund.de/download/gesetze/ BetrVG.pdf. For a review of the evolution of workplace codetermination in Germany, the innovations of the new law, and the controversies over costs and benefits of works councils, see Addison, Bellmann, Schnabel, and Wagner, 2002.

2 See Kommission Mitbestimmung 1998. An English-language summary of the final report of the Commission is available at: www.mpi-fg-koeln.mpg.de/endbericht/inhalt_e.html .
} 
1998, no less than 60 percent of all private-sector employees worked in firms without a works council (and without employee representatives on the supervisory board). Moreover, the Commission predicted a rise in this share for structural reasons; in particular, the growing importance of new service-sector establishments that are less likely than their manufacturing counterparts to have works councils.

Although works councils are a core element of the dual system of industrial relations in Germany, representative and up-to-date information on their frequency and coverage is sparse. Thus, there are no official statistics on works councils, and neither the union movement nor employers' associations publish pertinent information. We note parenthetically that in its draft proposals for a new Works Constitution Act, presented contemporaneously with the publication of the final report of the Codetermination Commission, the Federation of German Unions demanded registration of all enterprises without works councils in an accessible public register (see Deutscher Gewerkschaftsbund, 1998). This request did not find its way into the new law.

The present paper seeks to fill this deficit in our knowledge by providing up-to-date information on works council presence and coverage by establishment size interval and by broad sector for both western and eastern Germany, using data from the IAB establishment panel. Probit estimation of works council incidence is also offered. In addition, we document the extent of newly-established works councils and inquire into the circumstances of their formation.

The structure of the paper is as follows. Section II provides descriptive statistics on works councils for 2000. Section III investigates the determinants of works council presence. Section IV tackles the separate issue of newly-established councils. A brief interpretative section concludes.

\section{WoRKS COUNCILS IN GERMANY: FACTS AND FIGURES FOR 2000}

The descriptive statistics presented in this section are derived from the IAB establishment panel. Each year since 1993 (1996), this panel has surveyed several thousand establishments from all sectors of the economy in western (eastern) Germany. ${ }^{3}$ It is based on a stratified random sample - using strata for 16 industries and 10 size classes - from the population of all local production units

\footnotetext{
${ }^{3}$ For more information on the IAB establishment panel see Kölling (2000). The data are confidential but not exclusive. Those interested in using them for scientific (noncommercial) research should contact the second author via e-mail: lutz.bellmann@iab.de .
} 
with at least one employee covered by social insurance. (Due to the stratification of the sample, the following material is based on weighted data.) Note that privatesector undertakings which do not have insured employees cannot have a works council under the law (recall the employment size threshold of five permanent employees, noted earlier), so that from this perspective the restriction is not a problem. Nevertheless, it is the case that a small number of public-sector workplaces employing only civil servants, who are formally outside the social insurance system, are excluded from the IAB panel. Information on the works council status of establishments in western and eastern Germany is available for the 1996, 1998, and 2000 waves of the panel. For present purposes, we focus on the most recent figures for 2000 .

Table 1: Distribution and Coverage of Works Councils by Establishment Size in $\mathbf{2 0 0 0}$ (in percent, establishments with five employees or more)

\begin{tabular}{|c|c|c|c|c|c|c|}
\hline \multirow{2}{*}{$\begin{array}{l}\text { Establishment size } \\
\text { interval (number of } \\
\text { employees) }\end{array}$} & \multicolumn{2}{|c|}{ Western Germany } & \multicolumn{2}{|c|}{ Eastern Germany } & \multicolumn{2}{c|}{ Germany } \\
\cline { 2 - 7 } & Presence & Coverage & Presence & Coverage & Presence & Coverage \\
\hline $5-20$ & 9.3 & 10.5 & 7.8 & 9.8 & 9.1 & 10.4 \\
$21-50$ & 29.9 & 31.5 & 29.9 & 30.8 & 29.9 & 31.3 \\
$51-100$ & 52.9 & 53.4 & 51.2 & 51.3 & 52.6 & 53.0 \\
$101-200$ & 68.6 & 69.5 & 69.1 & 69.7 & 68.7 & 69.5 \\
$201-500$ & 81.4 & 82.5 & 76.2 & 77.4 & 80.6 & 81.8 \\
501 and above & 93.3 & 93.5 & 82.1 & 86.3 & 91.7 & 92.6 \\
\hline Average & 16.6 & 54.1 & 15.4 & 47.1 & 16.3 & 53.0 \\
\hline
\end{tabular}

Notes: Presence refers to the share of establishments with a works council. Coverage denotes the share of employees working in an establishment with a works council.

Source: IAB Establishment Panel, waves 8 (western Germany) and 5 (eastern Germany), 2000.

Table 1 reports information on works council presence (defined as the proportion of establishments with a works council) and coverage (the proportion of employees working in establishments with works councils) for the German economy as a whole, and for western and eastern Germany, by six establishment size classes. Only establishments with five or more employees are included in the 
sample due to the legal threshold mentioned above. On the basis of this restriction, works councils are encountered in just one in every six German establishments, and this share is only slightly higher in western than eastern Germany. Works council presence tends to increase sharply with establishment size, from about one in ten in the smallest size class with less than 21 employees to about nine in ten among the large firms with more than 500 employees. The big picture is rather similar in western and eastern Germany. Clearly, the positive association between establishment size and works council presence produces a value for coverage that considerably exceeds that for incidence - slightly more than one-half of all employees in Germany work in establishments that have a works council.

Table 2: Distribution and Coverage of Works Councils by Sector in $\mathbf{2 0 0 0}$ (in percent, establishments with five employees or more)

\begin{tabular}{|c|c|c|c|c|c|c|}
\hline \multirow{2}{*}{ Sector } & \multicolumn{2}{|c|}{ Western Germany } & \multicolumn{2}{|c|}{ Eastern Germany } & \multicolumn{2}{|c|}{ Germany } \\
\hline & Presence & Coverage & Presence & Coverage & Presence & Coverage \\
\hline Public sector & 62.9 & 88.9 & 67.4 & 90.2 & 63.5 & 89.2 \\
\hline $\begin{array}{l}\text { Private sector } \\
\text { (incl. Agriculture) }\end{array}$ & 12.4 & 47.5 & 11.8 & 37.0 & 12.3 & 45.8 \\
\hline $\begin{array}{l}\text { - Manufacturing } \\
\text { (incl. Construction) }\end{array}$ & 13.4 & 58.2 & 8.7 & 36.4 & 12.4 & 54.9 \\
\hline - Private services & 11.8 & 40.0 & 14.3 & 39.7 & 12.2 & 40.0 \\
\hline All sectors & 16.6 & 54.1 & 15.4 & 47.1 & 16.3 & 53.0 \\
\hline
\end{tabular}

Note: See notes to Table 1.

Source: IAB Establishment Panel, waves 8 (western Germany) and 5 (eastern Germany), 2000.

Both works council presence and coverage varies widely by sector. Table 2 shows that nearly two-thirds of all establishments in the public sector have a works council (termed a Personalrat) compared to only one in eight establishments in the private sector (where the works council is termed a Betriebsrat). Although these figures do not differ materially between western and eastern Germany, we find a remarkable difference in works council incidence when we split the private sector into its manufacturing (including construction) and services components. In west- 
ern Germany, works council presence is higher in manufacturing than in services, and folklore has it that the shrinking share of the manufacturing sector combined with a growing share of private services is one of the main reasons for the long-run decline of works council presence in (western) Germany. By contrast, in eastern Germany works council presence is much smaller in manufacturing than in services, while works council coverage in manufacturing is about 22 percentage points lower than in western Germany.

Table 3: Distribution of Works Councils by Establishment Size and Sector in 2000 (share of establishments with five employees or more that have a works council, in percent)

\begin{tabular}{|c|c|c|c|c|c|c|c|c|c|}
\hline \multirow{2}{*}{$\begin{array}{l}\text { Establishment } \\
\text { size interval } \\
\text { (number of } \\
\text { employees) }\end{array}$} & \multicolumn{2}{|c|}{ Western Germany } & \multicolumn{2}{|c|}{ Eastern Germany } & \multicolumn{3}{c|}{ Germany } \\
\cline { 2 - 10 } & $\begin{array}{l}\text { Manu- } \\
\text { facturing }\end{array}$ & $\begin{array}{l}\text { Private } \\
\text { Services }\end{array}$ & $\begin{array}{l}\text { Public } \\
\text { Sector }\end{array}$ & $\begin{array}{l}\text { Manu- } \\
\text { facturing }\end{array}$ & $\begin{array}{l}\text { Private } \\
\text { Services }\end{array}$ & $\begin{array}{l}\text { Public } \\
\text { Sector }\end{array}$ & $\begin{array}{l}\text { Manu- } \\
\text { facturing }\end{array}$ & $\begin{array}{l}\text { Private } \\
\text { Services }\end{array}$ & $\begin{array}{l}\text { Public } \\
\text { Sector }\end{array}$ \\
\hline $5-20$ & 3.0 & 7.2 & 51.7 & 2.7 & 8.4 & 46.9 & 3.0 & 7.4 & 51.2 \\
$21-50$ & 27.5 & 22.6 & 75.7 & 14.2 & 31.5 & 78.3 & 24.3 & 24.1 & 76.3 \\
$51-100$ & 54.6 & 40.4 & 84.2 & 42.9 & 46.5 & 94.5 & 52.4 & 41.5 & 85.7 \\
$101-200$ & 62.0 & 64.7 & 95.4 & 67.3 & 62.1 & 100.0 & 62.9 & 64.3 & 96.2 \\
$201-500$ & 85.3 & 71.2 & 93.3 & 79.4 & 67.8 & 97.9 & 84.7 & 70.6 & 94.0 \\
501 and above & 93.9 & 88.0 & 99.5 & 85.3 & 77.8 & 87.3 & 93.3 & 86.5 & 96.7 \\
\hline Average & 13.4 & 11.8 & 62.9 & 8.7 & 14.3 & 67.4 & 12.4 & 12.2 & 63.5 \\
\hline
\end{tabular}

Source: IAB Establishment Panel, waves 8 (western Germany) and 5 (eastern Germany), 2000.

Table 3 combines information on establishment size class and sector. In the public sector, about one-half of the smallest units have a Personalrat, and nearly all of the larger units with more than 100 employees have the institution. In the private sector in both western and eastern Germany, works council presence tends to increase with firm size in manufacturing and private services. Observe that in both regions works councils are a very rare species in the smallest establishments in the manufacturing sector. 
Since the public sector can be regarded as a special case where works councils are more or less part of the organization (and bureaucracy), it may be sensible to concentrate on the private sector and on employees' decisions to establish a works council there. The broad picture regarding works council presence and coverage in the private sector of the German economy at the start of the new millennium can be summarized as follows: works councils are elected in only one of every eight establishments, although this frequency increases with establishment size. It is larger for manufacturing than services in western Germany, and conversely for eastern Germany. But the positive relation between establishment size and works council presence means that the number of workers covered by councils is greater than the incidence of councils: no less than 47.5 (37) percent of all employees in western (eastern) Germany are working in works council establishments.

\section{The Determinants of Works Council Presence}

Why is it that so many establishments that could have a works council under the law do not in practice have one? Even if elections of works councils are neither mandated nor automatic, in a council-free regime all that is strictly necessary to bring about an election and thence a works council is for a small group of at least three employees (or a union that claims to have at least one member in the plant) to call for a works meeting where an electoral board will be elected which will in turn call the election, implement it, and announce the result. The requirements are hardly onerous. Given the far-reaching codetermination rights of the works council, the interesting question is why some establishments but not others are covered by the institution.

The first answer to this question can be found as a byproduct in the study by FitzRoy and Kraft (1987) of works councils' efficiency effects. The authors estimated a probit equation for the probability of observing a works council using a small sample of $61 / 62$ firms in the metal working industry in $1977 / 79$. They found that the probability of works council presence significantly rises with the number of employees and is lower in urban locations. Based on a much larger sample of 1,867 firms in the private sector in 1987, Frick and Sadowski (1995) presented (without further amplification) a logistic regression in which the dependent variable is a works council dummy. They reported that works councils are more likely the larger/older the firm and the more qualified its workforce. Firms experiencing greater difficulty in recruiting qualified personnel and those with large swings in labor demand were also found to be more likely to have a works council. Con- 
versely, works councils were less likely to be observed the higher the share of female workers and the greater the proportion of part-timers in the work force.

In a comprehensive study specifically focused on the determination of works council existence, Addison, Schnabel, and Wagner (1997) used data from a regional sample of manufacturing establishments in Lower Saxony, namely, the Hannover Firm Panel. ${ }^{4}$ Using data from the first wave of the panel, administered in 1994, the authors link works council presence to structural, worker composition, and participation variables. The key structural regressors are firm size (and its square), firm age, branch plant status, and a detailed set of (30) industry dummies. Our earlier descriptive material has already flagged the likely importance of establishment size. There are a number of factors that would lead us to anticipate a positive association between size and works council presence. Most important perhaps is the fact that the formal authority of the works council is increasing in establishment size, thereby providing an increased incentive for workers to elect a council in these circumstances. Governance considerations in larger plants might also lead both sides to embrace the institution. Less positively, the more routinized and regimented work settings commonly attributed to larger establishments might encourage workers to demand works councils on defensive grounds. For its part, branch plant status might capture any demonstration effect that the existence of a works council in a parent firm might have on its affiliate. Older plants might be more likely to have councils because of their more established traditions of collective representation, and/or different managerial ethos and type of workers. (As a practical matter, the Hannover panel does not provide a continuous measure of age, but rather information on whether the plant was established prior to 1960 or otherwise.)

Addison, Schnabel, and Wagner argue that certain characteristics of the workforce (and the workplace) may be expected to index a taste for representation on the part of employees. As cases in point, they identify the proportions of blue-collar workers, shift workers, females, and part-timers. It is postulated that the two former (latter) variables are likely to be positively (negatively) associated with works council presence for reasons that reflect both worker choice and organizational stability considerations.

\footnotetext{
${ }^{4}$ The population of the (four-wave) Hannover panel is all manufacturing firms with at least 5 employees. The sample of establishments is stratified by firm size, with over-sampling of larger plants. The first wave of the panel contains data on 1,025 establishments. For further information on this and the remaining three waves, see Brand, Carstensen, Gerlach, and Klodt (1996).
} 
Finally, the authors seek to test the argument that both direct and indirect participation variables - in the form of dummies for teamworking and profit sharing, respectively - might represent a substitute in the eyes of the workforce for the machinery of the works council, even if one of the functions of the works council encompasses codetermination rights in the implementation of such arrangements. They also consider profit-sharing schemes for managers, to test one aspect of the management pressure hypothesis advanced by FitzRoy and Kraft (1987, 1990) that such schemes will encourage management to seek compromise and thereby lessen the need for workers to elect works councils on defensive grounds.

Addison, Schnabel, and Wagner present probit estimates for the total sample of establishments and for a subsample of plants with 10-249 employees, within which interval works council incidence runs the full gamut. Across both samples, there is a consistent relation between the structural variables and works council presence. That is, the probability of there being a council increases with establishment size (albeit at a decreasing rate) and with the age of the plant, and is also greater if the establishment is a branch plant. As far as the taste for collective representation variables are concerned, these all behave in the expected manner, but only one of these - namely, the inverse indicator provided by the share of female employees is statistically significant throughout. The effect of the participation variables is interesting in that there is some suggestion that teamworking in particular is associated with a reduced probability of observing a works council. The same is true for the employee profit-sharing variable although in this case the coefficient estimate is poorly determined across both samples. As far as profit-sharing schemes for managers are concerned, these do not appear to reduce the likelihood of works council presence; if anything the evidence is to the contrary. ${ }^{5}$

The present empirical inquiry seeks to extend our former analysis, using data from the IAB Establishment Panel. Unlike its Hannover counterpart, this panel is nationally representative, covers sectors other than just manufacturing, and offers more recent data. Although our empirical strategy follows the lines of our earlier study,

\footnotetext{
${ }^{5}$ It should also be noted that the authors include a performance indicator - namely, an index of establishment profitability - in the estimating equation. If works councils offer a vehicle for appropriating rents, higher profitability may lead to works council formation. On the other hand, successful rent seeking behavior may be manifested in lower profitability, producing an oppositely signed coefficient estimate for the performance indicator. As it happens, the association is both negative and also well determined. However, the authors caution against simplistic rent seeking interpretation of this finding given the cross section nature of the estimation, and instead choose to emphasize that inclusion of the profits variable does not qualitatively alter any of the other results.
} 
the specification of our empirical model will differ somewhat from it, reflecting both data limitations and advantages of the IAB panel.

Commonalities include a quadratic in establishment size, a branch plant dummy, the percentages of blue-collar, part-time, and female workers, a dummy variable indicating whether or not the establishment has a profit sharing system for employees, and a set of industry dummies. Our priors as regards the ceteris paribus impact of these regressors have been discussed above.

Although establishment age is also included in the new model, its definition is different than before. We can no longer define older firms as those established before 1960 because we include firms from the new federal states in eastern Germany, most of which were founded (or subject to major restructuring) after unification in 1990. We now identify a young firm as one founded in 1995 or later. For the reasons noted earlier, we anticipate a negative impact of this (dummy) variable on works council presence. Furthermore, conventional wisdom decrees that the decline in works council presence in Germany is in part due to the fact that employees in newly established firms (notably, in the so-called 'new economy' and in several service sectors) do not elect works councils. Including a dummy for young firms allows us to test this conjecture.

Information on the percentage of shift workers, as well as the presence or otherwise of teamwork and profit sharing schemes for managers is not available from the current (2000) wave of the IAB panel. Furthermore, we did not include the current profit situation as a regressor, reflecting potential endogeneity problems. However, we introduce four new establishment characteristics and one regional variable to augment our earlier empirical treatment. First, information on the legal status of the firm is used. We deploy a dummy variable that takes the value of one if an establishment is a family-name business (Einzelunternehmen or Personengesellschaft). Typically, such firms are run by the owners themselves, and in a paternalistic manner. Often these 'old-fashioned capitalists' are hostile to works councils (and unions), and may manage to convince employees not to make use of their legal right to elect a works council. Accordingly, we expect a negative influence of this variable on works council presence. Second, we identify a foreign ownership variable, which assumes the value of one if the establishment is foreign owned (either entirely or in an amount exceeding 50 percent of equity), zero otherwise. Here we have no single valued expectations. On the one hand, there is abundant anecdotal evidence suggesting that multinational corporations headquartered in, say, the United States or Japan often regard the German system of industrial 
relations as a locational disadvantage (or Standortnachtei). To this extent, they may attempt to avoid the election of a works council. On the other hand, it might well be the case that foreign firms that decide to operate facilities in Germany do not share this vision, or that the employees of foreign-owned plants elect a works council as a defensive mechanism. In any event, given the palpable lack of hard evidence on the issue, inclusion of this variable is important in its own right. Third, we include a variable indicating whether or not an establishment is covered by a collective agreement with a union, governing pay and working conditions. The fact that works councils play a key role in monitoring the implementation and functioning of collective agreements inside the establishment would lead us to expect a positive association between these two worker representation institutions. ${ }^{6}$ Fourth, we include a variable indicating the presence (or otherwise) of an employee share ownership scheme. This dummy complements the profit sharing regressor and is justified on the same grounds.

Last but not least, we include a dummy variable that takes the value of one if the establishment is located in eastern Germany, and zero for the case of western Germany. Given that we control for establishment age, and in the light of the descriptive results provided in section II, it follows that we have no distinct priors regarding the ceteris paribus effect of an eastern German location on the probability of observing a works council.

As a first step, the empirical model was estimated across all establishments with five or more employees in the IAB panel for which information on each variable is available. ${ }^{7}$ Estimates for Germany as a whole, and for eastern and western Germany, are remitted to the Appendix Table. This exercise does not yield statistically significant coefficient estimates of opposing sign for the same variable as between the two regions. Given that we have no valid theoretical priors leading us to expect differential regional effects of the covariates, we shall not comment on differences between the two halves of the nation other than to note that including an east-west dummy suffices as a control variable. Further, since the descriptive material provided in section II indicates that the public sector differs fundamentally from the

\footnotetext{
${ }^{6}$ For an interesting game-theoretic discussion of the joint determination of membership of an employers association and works council presence, see Hübler and Jirjahn (2001).

${ }^{7}$ While the descriptive information on works council incidence and coverage is based on weighted data (taking care of the sampling frame using strata for 16 industries and 10 size classes), the econometric investigation in this and the following section uses unweighted data and all empirical models include the stratification variables (i.e. industry dummies and establishment size); see Winship and Radbill (1994) for a discussion.
} 
private sector in works council incidence, we propose to focus on findings for private-sector establishments (excluding agriculture) alone.

Table 4: Probit Estimates of Works Council Presence in the Private Sector (excluding agriculture and not-for-profit organizations)

\begin{tabular}{|c|c|c|c|}
\hline Variable & Private Sector & $\begin{array}{l}\text { Manufacturing/ } \\
\text { Construction }\end{array}$ & $\begin{array}{l}\text { Private } \\
\text { Services }\end{array}$ \\
\hline Constant & $\begin{array}{l}0.2879 \\
(1.79)\end{array}$ & $\begin{array}{l}-0.0180 \\
(-0.09)\end{array}$ & $\begin{array}{c}-0.3735^{\star \star} \\
(-2.80)\end{array}$ \\
\hline $\begin{array}{l}\text { Establishment size } \\
\text { (number of employees) }\end{array}$ & $\begin{array}{l}0.0033^{* *} \\
(10.65)\end{array}$ & $\begin{array}{l}0.0061^{* *} \\
(8.13)\end{array}$ & $\begin{array}{l}0.0024^{* *} \\
(6.64)\end{array}$ \\
\hline Establishment size squared & $\begin{array}{l}-7.86 \text { e- } 08^{* *} \\
(-10.64)\end{array}$ & $\begin{array}{l}-1.46 \text { e- } 07^{* *} \\
(-8.10)\end{array}$ & $\begin{array}{c}-1.91 \mathrm{e}-07^{* *} \\
(-6.83)\end{array}$ \\
\hline $\begin{array}{l}\text { Branch plant } \\
\text { (dummy: } 1 \text { if yes) }\end{array}$ & $\begin{array}{l}0.6140 * * \\
(13.64)\end{array}$ & $\begin{array}{l}0.6597^{\star *} \\
(8.16)\end{array}$ & $\begin{array}{l}0.5808^{* *} \\
(10.35)\end{array}$ \\
\hline $\begin{array}{l}\text { Establishment age } \\
\text { (dummy: } 1 \text { if } \leq 5 \text { years) }\end{array}$ & $\begin{array}{c}-0.2386^{* *} \\
(-4.13)\end{array}$ & $\begin{array}{c}-0.2542^{\star *} \\
(-2.68)\end{array}$ & $\begin{array}{c}-0.1652^{*} \\
(-2.11)\end{array}$ \\
\hline $\begin{array}{l}\text { Legal status of firm } \\
\text { (dummy: } 1 \text { if family-name firm) }\end{array}$ & $\begin{array}{l}-0.6420^{* *} \\
(-16.01)\end{array}$ & $\begin{array}{c}-0.4680^{* *} \\
(-7.66)\end{array}$ & $\begin{array}{l}-0.8051^{\star *} \\
(-12.94)\end{array}$ \\
\hline $\begin{array}{l}\text { Foreign ownership } \\
\text { (dummy: } 1 \text { if foreign owner) }\end{array}$ & $\begin{array}{l}0.2910^{* *} \\
(3.91)\end{array}$ & $\begin{array}{l}0.5014^{* *} \\
(3.70)\end{array}$ & $\begin{array}{c}0.0844 \\
(0.81)\end{array}$ \\
\hline $\begin{array}{l}\text { Covered by a collective agreement } \\
\text { (dummy: } 1 \text { if yes) }\end{array}$ & $\begin{array}{c}0.9172^{* *} \\
(23.48)\end{array}$ & $\begin{array}{c}0.8893^{* *} \\
(14.72)\end{array}$ & $\begin{array}{l}0.9103^{* *} \\
(16.38)\end{array}$ \\
\hline $\begin{array}{l}\text { Blue-collar workers } \\
\text { (percentage) }\end{array}$ & $\begin{array}{c}-0.0048^{* *} \\
(-7.19)\end{array}$ & $\begin{array}{c}-0.0002 \\
(-0.19)\end{array}$ & $\begin{array}{c}-0.0069^{* *} \\
(-8.48)\end{array}$ \\
\hline $\begin{array}{l}\text { Part-time workers } \\
\text { (percentage) }\end{array}$ & $\begin{array}{c}-0.0025^{\star} \\
(-2.15)\end{array}$ & $\begin{array}{c}-0.0165^{\star *} \\
(-4.47)\end{array}$ & $\begin{array}{c}0.0013 \\
(1.07)\end{array}$ \\
\hline $\begin{array}{l}\text { Female workers } \\
\text { (percentage) }\end{array}$ & $\begin{array}{c}-0.0022^{\star \star} \\
(-2.58)\end{array}$ & $\begin{array}{l}-0.0011 \\
(-0.74)\end{array}$ & $\begin{array}{c}-0.0036^{\star *} \\
(-3.39)\end{array}$ \\
\hline $\begin{array}{l}\text { Profit sharing scheme for employees } \\
\text { (dummy: } 1 \text { if yes) }\end{array}$ & $\begin{array}{l}0.1500^{* *} \\
(2.88)\end{array}$ & $\begin{array}{l}0.3149^{* \star} \\
(3.72)\end{array}$ & $\begin{array}{c}-0.0272 \\
(-0.38)\end{array}$ \\
\hline $\begin{array}{l}\text { Employee share ownership scheme } \\
\text { (dummy: } 1 \text { if yes) }\end{array}$ & $\begin{array}{c}0.3422^{\star *} \\
(4.07)\end{array}$ & $\begin{array}{c}0.3892^{\star *} \\
(2.68)\end{array}$ & $\begin{array}{c}0.2778^{*} \\
(2.54)\end{array}$ \\
\hline Eastern Germany (dummy) & $\begin{array}{c}-0.1165^{\star *} \\
(3.26)\end{array}$ & $\begin{array}{c}-0.2955^{\star *} \\
(-5.40)\end{array}$ & $\begin{array}{c}0.1077^{*} \\
(2.08)\end{array}$ \\
\hline Industry dummies & yes $^{* *}$ & yes $^{* *}$ & yes $^{\star *}$ \\
\hline $\begin{array}{l}\mathrm{n} \\
\text { Pseudo } \mathrm{R}^{2}\end{array}$ & $\begin{array}{c}8,688 \\
0.3830\end{array}$ & $\begin{array}{c}4,403 \\
0.4675\end{array}$ & $\begin{array}{c}4,285 \\
0.3441\end{array}$ \\
\hline
\end{tabular}

Notes: Heteroscedastic-consistent t-values in parentheses. ${ }^{* *},{ }^{*}$ denote statistical significance at the 0.01 and 0.05 levels, respectively.

Source: IAB Establishment Panel, Waves 8 (western Germany) and 5 (eastern Germany), 2000. 
Probit estimates for the entire private sector and its manufacturing and service sector components are given in Table 4 . It is apparent that the determinants of works council presence differ as between manufacturing (including construction) and services. But the big picture at least is the same for establishments from both sectors with respect to firm size. Here, we observe the familiar inverse U-shaped relation between number of employees and the probability of observing a works council (see Addison, Schnabel, and Wagner, 1997). The same holds for the impact of branch plant status, establishment age, the legal status of the firm, foreign ownership, and coverage by a collective agreement. In each sector, and in accordance with our priors, the probability of works council presence in young establishments and family-name firms is lower, and it is higher in branch plants and in establishments covered by a collective agreement, ceteris paribus. Note that foreign-owned firms evince a higher probability of having a works council in manufacturing and construction. This particular result might come as a surprise to many, given popular opinion.

Material differences between services and the rest of the private sector are found for variables that reflect workforce composition, namely, the shares of blue-collar workers, part-time workers, and female workers. For manufacturing establishments, only the negative effect of an increasing share of part-time workers on works council presence is statistically significant at conventional levels. And for the sample of service-sector establishments only the directional influence of the share of female workers is as anticipated (and statistically significant). Expressed another way, the coefficient estimate for the share of part-time workers is positive (albeit insignificant), while the probability of observing a works council actually decreases as the proportion of blue-collar workers increases. We have no explanation for the latter seemingly perverse result.

As regards the effect of the (indirect) participation variables - namely, employee profit sharing and employee share ownership schemes - the evidence is also contrary to that reported in Addison, Schnabel, and Wagner (1997). That is to say, the availability of share ownership mechanisms is associated with an increased likelihood of observing works councils in both sectors. The same obtains for profit sharing, at least in manufacturing. One possibility is that firms with works councils, and perhaps more importantly works councilors themselves, have become less averse to such employee involvement schemes in recent years, and that this development has dominated any opposing tendency for such schemes to function as an alternative to the mechanism of representative employee involvement. 
A final result is that the regional influence is not constant as between sectors. Being located in eastern Germany increases the probability of works council presence in service-sector establishments while the opposite result holds for their manufacturing counterparts.

Up to this point our discussion has devolved on issues of the statistical significance of the estimated coefficients and the directional influence of the covariates. But information on the extent of this influence - the issue of economic significance - is even more important. Although a variable that has no statistically significant impact can be ignored from an economic point of view, the opposite is not true. That is to say, a variable that is highly statistically significant might have no material impact. If, for example, the estimated probability of having a works council diminishes by 0.1 percent when observed plant size falls from 250 to just 20 employees, we can ignore plant size in any discussion of works council incidence, irrespective of a high level of statistical significance indicated by the prob-value.

Unfortunately, the estimated coefficients from a probit model (or any other nonlinear model) cannot easily be used to make statements about the size of the ceteris paribus effect of a change in the value of an exogenous variable (such as an increase in the size of an establishment by, say, 5 persons) on the value of the endogenous variable (here the probability of having a works council). This is because the size of the effect depends on both the starting level of the exogenous variable under consideration and on the values of all other variables in the model (see Long and Freese, 2001, 87ff.).

One way to ease interpretation of the estimates is to compute the estimated values of the endogenous variable (the probability of having a works council) for a plant with certain characteristics (38 employees, 24 percent blue-collar workers, etc.), and then to see how a change in the value of one exogenous variable (such as establishment size) changes the estimated probability. Where there are many regressors, however, this procedure tends to produce results that are difficult to survey. One solution is to construct a limited number of types of plant, using different values of selected variables that are both statistically significant and economically important - for example, establishment size and collective bargaining coverage - while fixing the values of the other variables in the empirical model at their sample means in the case of continuous variables (e.g. proportion of part-time workers) or at the most common frequency for dichotomous variables (e.g. foreign ownership). 
For expositional purposes, we focus here on the ceteris paribus influence of differences in establishment size, legal status (family-name firm) and coverage by a collective agreement on the estimated probability of having a works council in either manufacturing and construction or private services. In each sector, all three variables are highly statistically significant in the estimations for works council presence. Moreover, legal status and coverage by a collective agreement are quite common outcomes. Thus, 33 (42) percent of all establishments in manufacturing and construction (private services) are family-name businesses, while 68 (53) percent of all establishments in manufacturing and construction (private services) are covered by a collective agreement. In the simple simulation exercise reported below, the above mentioned variables take different values whereas these values are fixed for all other arguments. (The hypothetical establishment is not a branch plant; it is not a young firm or foreign owned; it has neither a profitsharing scheme for employees nor an employee stock ownership plan; it is located in western Germany and produces in the reference group industry; and the proportions of blue-collar, part-time, and female employees are fixed at the respective sample means.)

To start with, consider a plant from manufacturing and construction that is small (having just 20 employees), a family-name firm, and not covered by a collective agreement. Call this plant $1 \mathrm{~A}$. Using the results reported in the penultimate column of Table 4, and fixing the values of the other variables in the manner stated above, the estimated probability of having a works council for plant $1 \mathrm{~A}$ is 0.30 . If we change the legal status to that of a non-family-name plant (call this plant $2 A$ ), the estimated probability increases to 0.48 . This example nicely illustrates the large impact of the legal status of the entity on works council presence. In establishment $3 \mathrm{~A}$ - identical to plant $2 \mathrm{~A}$ in every respect other than being covered by a collective agreement - this probability is 0.80 . Evidently, the effect of collective agreement coverage on the probability of observing a works council is huge.

To illustrate the role of establishment size, we identify three new plants - call them $1 \mathrm{~B}, 2 \mathrm{~B}$, and $3 \mathrm{~B}-$ that are identical to $1 \mathrm{~A}, 2 \mathrm{~A}$, and $3 \mathrm{~A}$ other than in their number of employees. The new plants each employ 250 (rather than 20) employees. The estimated probabilities of observing a works council in $1 \mathrm{~B}, 2 \mathrm{~B}$, and $3 \mathrm{~B}$ are 0.81 , 0.91 , and 0.99 , respectively, much higher than for their smaller counterparts. Clearly, establishment size is very important in this sector. As an aside, we note that, taken literally, the estimated coefficients from our empirical model point to an inverse U-shaped relation between number of employees and the probability of works council presence. Accordingly, this probability should decline after some 
establishment size threshold: the estimated maximum value of this quadratic in employment size is 21,010 employees. Only a handful of plants in our sample have more employees. It follows that the results should only be interpreted as indicating that works council presence increases with firm size but at a decreasing rate.

We replicated the above simulations for service-sector establishments that were designed as twins of plants $1 \mathrm{~A}$ through $3 \mathrm{~B}$. The broad picture for the service sector is quite similar to that for manufacturing. Thus, the probability of works council presence is definitely lower in a family-name firm $\left(0.06\right.$ in Firm $1 \mathrm{~A}^{\prime}$ compared with 0.23 in Firm $2 A^{\prime}$ ), and also higher in a firm covered by a collective agreement (0.57 in Firm 3A'). Again, establishment size is important: the estimated probabilities are $0.16,0.43$, and 0.77 for plants $1 \mathrm{~B}^{\prime}, 2 \mathrm{~B}^{\prime}$, and $3 \mathrm{~B}^{\prime}$, respectively.

\section{NeW Works Councils: EXTENT AND DETERMINANTS}

Following our investigation of the determinants of works council presence in 2000 we will now turn to the separate issue of works council introduction. Using data from the $I A B$ establishment panel, we identify newly established works councils and investigate the circumstances of their formation.

To the best of our knowledge, this issue has nowhere been examined in the literature. ${ }^{8}$ Empirical evidence on formation is important, not least because a central aim of the German government in revising the Works Constitution Act was to foster the introduction of works councils in small firms and thereby shrink the size of what was termed a 'codetermination-free zone' (see section I).

Information on works council presence for establishments in western and eastern Germany is available from the 1996, 1998, and 2000 waves of the IAB establishment panel. Comparing establishments in 1996 and 1998 (and those in 1998 with 2000) one can identify plants reporting no works council in the base year(s) that introduced the entity sometime within the next two years. Thus, of the 2,321 plants participating in both the 1996 and 1998 waves that reported no works council in the former year, 121 (or 5.21 percent) claimed to have a council in 1998. The

\footnotetext{
${ }^{8}$ Note, however, that it is touched upon in our earlier study of the effects of works councils on firm performance (see Addison, Bellmann, Schnabel and Wagner 2002). There we applied a propensity score based Mahalanobis-distance approach to match plants, using a probit model of works council introduction to compute the propensity score.
} 
corresponding values for the 1998 and 2000 waves are 2,563 and 145 (or 5.66 percent), respectively.

Works council formation, therefore, is a rare event in Germany. In what follows, we use probit estimates of works council introduction to investigate the distinguishing characteristics of plants with recently established councils. In the empirical model, we also look at the ceteris paribus effects of variables (measured in the base year of each of the two periods, 1996/98 and 1998/2000) that might be considered as potential determinants of works council formation.

As was the case for works council presence, our main regressors capture structural and worker compositional elements. The former comprise a quadratic in establishment size, branch plant status, establishment age (not available in 1998), the legal status of the firm, coverage by a collective agreement, location in eastern Germany, and industry affiliation. Justification for these arguments is identical to that provided earlier. Again as before, the worker compositional variables are intended to proxy a taste for collective representation on the part of employees. The variables in question, the proportions of blue collar, part-time, and female workers, are on this occasion supplemented by the share of shift workers (available in 1996 and 1998 only).

Moreover, given the popular belief that works council introduction may reflect a defensive reaction on the part of workers to some form of workplace crisis, we include a measure of the establishments profit situation. This subjectively defined variable takes the value of one if the management respondent reports the profit situation to be either 'very good' or 'good', zero otherwise. Although this financial performance variable might suffer from various shortcomings, we consider it a valid indicator of overall business conditions in the establishment. ${ }^{9}$

For the period 1996/98 information for each of the above variables is available for 1,950 establishments; 80 of which introduced a works council. For 1998/2000, the respective values are 2,294 and 109 plants.

\footnotetext{
${ }^{9}$ In analyzing works council formation, lack of information on employee profit-sharing schemes/ stock ownership plans and foreign ownership in the 1996 and 1998 waves precluded use of these variables, each of which were employed in modeling works council presence (see Table 4).
} 
Table 5: Probit Estimates of Works Council Introduction

\begin{tabular}{|c|c|c|}
\hline Variable & $\begin{array}{l}\text { No works council in } \\
1996, \text { but one in } 1998\end{array}$ & $\begin{array}{c}\text { No works council in } \\
1998, \text { but one in } \\
2000\end{array}$ \\
\hline Constant & $\begin{array}{l}-1.3999^{* *} \\
(-3.04)\end{array}$ & $\begin{array}{l}-1.0266^{* *} \\
(-3.56)\end{array}$ \\
\hline $\begin{array}{l}\text { Establishment size } \\
\text { (number of employees) }\end{array}$ & $\begin{array}{c}0.0037^{* *} \\
(4.13)\end{array}$ & $\begin{array}{c}0.0010^{*} \\
(2.19)\end{array}$ \\
\hline Establishment size squared & $\begin{array}{l}-2.48 \mathrm{e}-6^{*} \\
(-2.52)\end{array}$ & $\begin{array}{l}-9.06 \text { e-8 } \\
(-1.14)\end{array}$ \\
\hline $\begin{array}{l}\text { Branch plant } \\
\text { (dummy: } 1 \text { if yes) }\end{array}$ & $\begin{array}{l}0.6210^{* *} \\
(4.69)\end{array}$ & $\begin{array}{l}0.5813^{* *} \\
(4.68)\end{array}$ \\
\hline $\begin{array}{l}\text { Establishment age } \\
\text { (dummy: } 1 \text { if < } 5 \text { years) }\end{array}$ & $\begin{array}{l}0.1183 \\
(0.94)\end{array}$ & [not available] \\
\hline $\begin{array}{l}\text { Legal status of firm } \\
\text { (dummy: } 1 \text { if family-name firm) }\end{array}$ & $\begin{array}{c}-0.3568^{* *} \\
(-2.71)\end{array}$ & $\begin{array}{c}-0.3928^{\star *} \\
(-3.55)\end{array}$ \\
\hline $\begin{array}{l}\text { Covered by a collective } \\
\text { agreement } \\
\text { (dummy: } 1 \text { if yes) }\end{array}$ & $\begin{array}{c}0.2324 \\
(1.82)\end{array}$ & $\begin{array}{l}0.3239^{* *} \\
(3.21)\end{array}$ \\
\hline $\begin{array}{l}\text { Blue-collar workers } \\
\text { (percentage) }\end{array}$ & $\begin{array}{c}-0.0033 \\
(-1.59)\end{array}$ & $\begin{array}{l}0.0029 \\
(1.50)\end{array}$ \\
\hline $\begin{array}{l}\text { Part-time workers } \\
\text { (percentage) }\end{array}$ & $\begin{array}{c}-0.0012 \\
(-0.42)\end{array}$ & $\begin{array}{l}-0.0017 \\
(-0.64)\end{array}$ \\
\hline $\begin{array}{l}\text { Female workers } \\
\text { (percentage) }\end{array}$ & $\begin{array}{c}-0.0029 \\
(-1.18)\end{array}$ & $\begin{array}{l}0.0006 \\
(0.25)\end{array}$ \\
\hline $\begin{array}{l}\text { Shift workers } \\
\text { (percentage) }\end{array}$ & $\begin{array}{l}0.0031 \\
(1.42)\end{array}$ & [not available] \\
\hline $\begin{array}{l}\text { Profit situation } \\
\text { (dummy: } 1 \text { if 'very good' or 'good') }\end{array}$ & $\begin{array}{l}0.0061 \\
(0.05)\end{array}$ & $\begin{array}{c}0.0571 \\
(0.57)\end{array}$ \\
\hline Eastern Germany (dummy) & $\begin{array}{c}-0.4155^{\star *} \\
(-3.23)\end{array}$ & $\begin{array}{c}-0.1211 \\
(-1.21)\end{array}$ \\
\hline Industry dummies & yes & yes $^{* *}$ \\
\hline$n$ & 1,950 & 2,294 \\
\hline Pseudo $\mathrm{R}^{2}$ & 0.150 & 0.129 \\
\hline
\end{tabular}

Notes: Heteroscedastic-consistent t-values in parentheses. ${ }^{* *}$, ${ }^{*}$ denote statistical significance at the 0.01 and 0.05 levels, respectively. All variables are for the first year indicated, either 1996 or 1998.

Source: IAB Establishment Panel.

Results of fitting the probit regressions to the data for 1996/98 and 1998/ 2000 are provided in Table 5 . In both periods, there is a positive association between estab- 
lishment size, branch plant status and coverage by a collective agreement, and works council formation. There is also a consistently negative relation between legal status and works council introduction. Both sets of result are in line with our priors.

Contrary to folklore, there is no suggestion that overall business conditions (i.e. profit situation) matter in either period. The same holds for each of the four worker composition variables, and also for the establishment age argument (included in the 1996/98 estimation alone for reasons of data availability).

For its part, location in eastern Germany reduces the probability of works council introduction. However, this effect is statistically significant at conventional levels only for the first period investigated.

To look at the economic significance of three of the variables found to be statistically significant throughout - namely, establishment size, coverage by a collective agreement, and legal status - a simulation exercise is performed that mimics our procedure in the previous section. That is, we consider a hypothetical plant with certain characteristics, compute the probability of works council formation for this plant based on the relevant coefficient estimates (reported in Table 5), and then alter the value of the variables under consideration sequentially so as to illustrate their ceteris paribus impact.

The simulation uses the results for 1996/98, reported in the second column of Table 5. The hypothetical plant $1 \mathrm{~A}$ has 20 employees, is a family-name business, and is not covered by collective agreement. Furthermore, this plant - and indeed all the other hypothetical establishments considered here - is not a branch plant; it is not a young plant; it has neither a 'very good' nor a 'good' profit situation; it is located in western Germany and operates in the reference group industry; and has proportions of blue-collar, part-time, female, and shift employees that are fixed at their sample means. The estimated probability of introducing a works council for Firm $1 \mathrm{~A}$ is a tiny 0.025 . Changing the legal status of the establishment firm (call this establishment type $2 \mathrm{~A}$ ) raises the probability to 0.054 . Despite the very considerable increase in the likelihood of works council, it remains the case that the probability value is low. In plant type $3 \mathrm{~A}$ - identical to establishment $2 \mathrm{~A}$ in all respects other than collective agreement coverage -, the probability of works council formation is $\mathbf{0 . 0 8 4}$, much higher than that for establishment type $2 \mathrm{~A}$ but still modest. 
To illustrate the contribution of establishment size, we compare our three types of plants $(1 \mathrm{~A}, 2 \mathrm{~A}$, and $3 \mathrm{~A})$ with otherwise identical establishments that have 250 (rather than 20) employees, and which we duly designate as 1B, 2B, and 3B. The estimated probability of observing works council introduction for the latter group are $0.102,0.181$, and 0.248 , respectively. These are much higher values than obtained for the smaller comparators. As was the case for legal status and collective agreement coverage, establishment size is an important determinant of council formation. Equally, however, the magnitude of the absolute values indicate that the introduction of a works council is expected to be a rare event not only in small plants but also in medium-sized establishments too.

\section{CONCLUDING REMARKS}

This paper has provided the most comprehensive information to date on the incidence and coverage of German works councils by establishment size class and by broad sector and region. Furthermore, it has offered an analysis of the determinants of works council presence, supplementing this with information on the frequency of new councils and the factors underpinning their formation.

Our basic findings are threefold. First of all, works councils are far from ubiquitous in the firmament of smaller establishments. In 2000 , only 9 percent (30 percent) of all establishments with 5-20 employees (21-50 employees) had a works council. The values are even lower when we single out the private sector. Given that smaller plants comprise a large fraction of the total, works councils are found in just 12.3 percent of German private sector-establishments with 5 or more employees. Nevertheless, reflecting greater works council penetration in larger establishments, a much higher proportion of German workers than German plants are covered by works councils: 45.8 percent in the private sector, and 89.2 percent in the public sector.

Second of all, works council presence is not random. Most importantly, in the private sector it tends to be positively related to establishment size and coverage by a collective agreement, and it is much lower in family-name businesses.

Finally, introduction of a new works council is a very rare event. Less than 6 percent of all establishments in the IAB panel that did not have a works council in 1996 (1998) reported having one in 1998 (2000). The probability of observing new councils is positively related to establishment size and coverage by a collective agreement, and it is again much lower in family-name undertakings. 
Given the scarcity of detailed, representative, and contemporary information on works council frequency, the descriptive evidence provided here has intrinsic worth. Furthermore, it is relevant for at least two other reasons. Thus, the nonrandom nature of works council presence/formation means that potentially serious biases characterize point estimates of the work council effect on firm performance derived from OLS estimation. With a few exceptions - recent examples being the very different methodological approaches of Hübler and Jirjahn (2001) and Addison, Bellman, Schnabel, and Wagner (2002) - the literature has treated works councils as exogenous. Moreover, the rare events nature of works council introduction in hitherto uncovered plants, and the core role of establishment size in this regard, make it highly improbable that the central aim of the new Works Constitution Act will be met. That aim is to shrink the extent of the codetermination free zone, which is largely made up of smaller establishments. Moreover, given the important role of bargaining coverage for works council presence, the steadily falling number of establishments covered by collective agreements reported by Kohaut and Schnabel (2001) is likely to increase this works council free zone.

A postscript is in order. After this paper was completed, the first round of regular works council elections under the aegis of new law was held (between March 1 and May 31, 2002). Time will tell whether or not the legislative changes and the intensive PR campaign of the union movement will lead to a large number of new works councils in small and medium-sized establishments. Based on our findings, we doubt this will happen. But we plan carefully to monitor such developments - and the economic effects of new councils - in future work. 


\section{LITERATURE}

Addison, John T. / Schnabel, Claus / Wagner, Joachim (1997): On the Determinants of Mandatory Works Councils in Germany, Industrial Relations 36, 419-445.

Addison, John T. / Bellmann, Lutz / Schnabel, Claus / Wagner, Joachim (2002): The Long Awaited Reform of the German Works Constitution Act, Universität Lüneburg, Fachbereich Wirtschafts- und Sozialwissenschaften, Arbeitsbericht Nr. 254, January (also available as IZA Discussion Paper 422).

Brand, Ruth / Carstensen, Vivian / Gerlach, Knut / Klodt, Thomas (1996): The Hannover Firm Panel, Discussion Paper No. 2, Universität Hannover.

Deutscher Gewerkschaftsbund [Bundesvorstand] (1998): Novellierungsvorschläge des DGB zum Betriebsverfassungsgesetz 1972, Düsseldorf: Deutscher Gewerkschaftsbund, Februar.

FitzRoy, Felix R. / Kraft, Kornelius (1987): Efficiency and Internal Organization: Works Councils in West German Firms, Economica 54, 493-504.

FitzRoy, Felix R. / Kraft, Kornelius (1990): Innovation, Rent Sharing, and the Organization of Labour in the Federal Republic of Germany, Small Business Economics 2, 95-103.

Frick, Bernd / Sadowski, Dieter (1995): Works Councils, Unions, and Firm Performance, in: Buttler, Friedrich et al. (Eds.), Institutional Frameworks and Labor Market Performance - Comparative Views on the U.S. and German Economies, London and New York: Routledge, 46-81.

Hübler, Olaf / Jirjahn, Uwe (2001): Works Councils and Collective Bargaining in Germany: The Impact on Productivity and Wages, Discussion Paper No. 332, Institute for the Study of Labor (IZA), Bonn, July.

Kölling, Arnd (2000): The IAB Establishment Panel, Schmollers Jahrbuch / Journal of Applied Social Science Studies 120, 291-300.

Kohaut, Susanne / Schnabel, Claus (2001): Tarifverträge - nein danke!? Einflussfaktoren der Tarifbindung west- und ostdeutscher Betriebe, Diskussionspapiere Friedrich-Alexander-Universität Erlangen-Nürnberg / Lehrstuhl für Arbeitsmarkt- und Regionalpolitik, No. 8, Dezember.

Kommission Mitbestimmung (1998): Mitbestimmung und neue Unternehmenskulturen - Bilanz und Perspektiven. Gütersloh: Verlag Bertelsmann Stiftung.

Long, J. Scott / Freese, Jeremy (2001): Regression Models for Categorical Dependent Variables using Stata, College Station, TX: Stata Press.

Winship, Christopher / Radbill, Larry (1994): Sampling Weights and Regression Analysis, Sociological Methods \& Research 23, 230-257. 
Appendix Table: Probit Estimates of Works Council Presence

\begin{tabular}{|c|c|c|c|}
\hline Variable & Germany & Western Germany & Eastern Germany \\
\hline Constant & $\begin{array}{l}-1.0624^{* *} \\
(-7.75)\end{array}$ & $\begin{array}{l}0.1121 \\
(0.56)\end{array}$ & $\begin{array}{l}0.3401 \\
(1.32)\end{array}$ \\
\hline $\begin{array}{l}\text { Establishment size } \\
\text { (number of employees) }\end{array}$ & $\begin{array}{c}0.0032^{* *} \\
(11.79)\end{array}$ & $\begin{array}{l}0.0039^{* *} \\
(7.50)\end{array}$ & $\begin{array}{l}0.0032^{* *} \\
(8.78)\end{array}$ \\
\hline Establishment size squared & $\begin{array}{l}-7.71 \mathrm{e}-08^{* *} \\
(-11.78)\end{array}$ & $\begin{array}{l}-9.23 e-08^{* *} \\
(-7.50)\end{array}$ & $\begin{array}{l}-6.14 \mathrm{e}-07^{* *} \\
(-8.52)\end{array}$ \\
\hline $\begin{array}{l}\text { Branch plant } \\
\text { (dummy: } 1 \text { if yes) }\end{array}$ & $\begin{array}{c}0.6030^{* *} \\
(14.51)\end{array}$ & $\begin{array}{l}0.7230^{* *} \\
(13.38)\end{array}$ & $\begin{array}{l}0.4359^{\star *} \\
(6.35)\end{array}$ \\
\hline $\begin{array}{l}\text { Establishment age } \\
\text { (dummy: } 1 \text { if } \leq 5 \text { years) }\end{array}$ & $\begin{array}{l}-0.2770^{* *} \\
(-4.89)\end{array}$ & $\begin{array}{c}-0.1519^{*} \\
(-2.14)\end{array}$ & $\begin{array}{c}-0.3871^{* *} \\
(-3.91)\end{array}$ \\
\hline $\begin{array}{l}\text { Legal form of firm } \\
\text { (dummy: } 1 \text { if family-owned firm) }\end{array}$ & $\begin{array}{l}-0.6905^{\star \star} \\
(-17.37)\end{array}$ & $\begin{array}{c}-0.5425^{\star *} \\
(-11.33)\end{array}$ & $\begin{array}{l}-1.0243^{* *} \\
(-11.75)\end{array}$ \\
\hline $\begin{array}{l}\text { Foreign ownership } \\
\text { (dummy: } 1 \text { if foreign ownership) }\end{array}$ & $\begin{array}{l}0.2617^{* *} \\
(3.49)\end{array}$ & $\begin{array}{c}0.1053 \\
(1.19)\end{array}$ & $\begin{array}{l}0.6626^{\star *} \\
(4.22)\end{array}$ \\
\hline $\begin{array}{l}\text { Covered by a collective agreement } \\
\text { (dummy: } 1 \text { if yes) }\end{array}$ & $\begin{array}{c}0.9758^{* *} \\
(26.66)\end{array}$ & $\begin{array}{c}0.8707^{* *} \\
(17.43)\end{array}$ & $\begin{array}{l}1.0576 * * \\
(18.57)\end{array}$ \\
\hline $\begin{array}{l}\text { Blue-collar workers } \\
\text { (percentage) }\end{array}$ & $\begin{array}{c}-0.0060^{* \star} \\
(-9.50)\end{array}$ & $\begin{array}{c}-0.0066^{\star *} \\
(-7.96)\end{array}$ & $\begin{array}{c}-0.0053^{\star *} \\
(-5.45)\end{array}$ \\
\hline $\begin{array}{l}\text { Part-time workers } \\
\text { (percentage) }\end{array}$ & $\begin{array}{c}-0.0033^{* \star} \\
(-3.52)\end{array}$ & $\begin{array}{c}-0.0011 \\
(0.85)\end{array}$ & $\begin{array}{c}-0.0062^{* *} \\
(-4.37)\end{array}$ \\
\hline $\begin{array}{l}\text { Female workers } \\
\text { (percentage) }\end{array}$ & $\begin{array}{c}-0.0021^{\star \star} \\
(-2.69)\end{array}$ & $\begin{array}{c}-0.0049^{* *} \\
(-4.73)\end{array}$ & $\begin{array}{r}0.0021 \\
(1.73)\end{array}$ \\
\hline $\begin{array}{l}\text { Profit sharing scheme for employees } \\
\text { (dummy: } 1 \text { if yes) }\end{array}$ & $\begin{array}{c}0.1100^{*} \\
(2.12)\end{array}$ & $\begin{array}{c}0.0173 \\
(0.28)\end{array}$ & $\begin{array}{l}0.3703^{* *} \\
(3.70)\end{array}$ \\
\hline $\begin{array}{l}\text { Employee share ownership scheme } \\
\text { (dummy: } 1 \text { if yes) }\end{array}$ & $\begin{array}{l}0.3005^{\star *} \\
(3.67)\end{array}$ & $\begin{array}{c}0.3555^{\star *} \\
(3.45)\end{array}$ & $\begin{array}{l}0.1302 \\
(0.90)\end{array}$ \\
\hline Eastern Germany (dummy) & $\begin{array}{l}-0.1201^{\star *} \\
(3.64)\end{array}$ & -- & -- \\
\hline Industry dummies & yes $^{* *}$ & yes $^{* *}$ & yes $^{* *}$ \\
\hline$n$ & 10,515 & 6,498 & 4,017 \\
\hline Pseudo $\mathrm{R}^{2}$ & 0.4206 & 0.4281 & 0.4388 \\
\hline
\end{tabular}

Notes: Heteroscedastic-consistent t-values in parentheses. ${ }^{* *},{ }^{*}$ denote statistical significance at the 0.01 and 0.05 levels, respectively.

Source: IAB Establishment Panel, waves 8 (western Germany) and 5 (eastern Germany), 2000. 
In der Diskussionspapierreihe sind bisher erschienen:

Previously published Discussion Papers:

1 Addison J.T., Die mitbestimmungsfreie Zone aus ökonoSchnabel C., mischer Sicht

Wagner J.

2 Jahn E.J., $\quad$ Substitution and Crowding-Out Effects of Wagner T. Active Labour Market Policy

3 Wegener T. Institutionelle Aspekte der Regionalisierung von Wirtschafts- und Strukturpolitik

4 Kölling, A., Bremst das Schwerbehindertengesetz die Schnabel, C., Arbeitsplatzdynamik in Kleinbetrieben? Wagner, J.

5 Schnabel, C., Verbreitung und Bestimmungsgründe Wagner, J. verschiedener Formen der Arbeitnehmerpartizipation in Industriebetrieben

6 Jahn E.J.,

Labour's Law?

$05 / 2000$

Wagner $\mathrm{T}$.

7 Niederalt, M., Schnabel, C.

Betriebliches Ausbildungsverhalten zwischen Kosten-Nutzen-Kalkül und gesellschaftlicher Kaiser, Chr. Verantwortung - Einflussfaktoren der Ausbildungsintensität von deutschen Betrieben

8 Kohaut, S. Tarifverträge - nein danke!? Einflussfaktoren Schnabel, C. der Tarifbindung west- und ostdeutscher Betriebe

9 Jahn, E.J. Brauchen wir einen allgemeinen Kündigungsschutz?

10 Addison, J.T., German Works Councils Old and New: Bellmann, L., Incidence, Coverage and Determinants Wagner, J. 